\title{
Apresentação
}

\section{0: 0 ano de grandes mudanças para os Cadernos Ibero-Americanos de Direito Sanitário}

\section{Foreword}

2020: the year of great changes for Ibero-American Journal of Health Law

\section{Presentación}

2020: el año de grandes cambios para os Cuadernos Iberoamericanos de Derecho Sanitario

Nascido em 2012 com o objetivo de difundir e estimular o desenvolvimento do Direito Sanitário na região ibero-americana, em 2020 os Cadernos Ibero-Americanos de Direito Sanitário (CIADS) assumem o desafio de ampliar seu alcance geográfico e se tornar mais internacional na discussão dos desafios contemporâneos sobre a Saúde e o Direito.

Para tanto, apresenta mudanças no conselho editorial, incorporando colaboradores da Universidade de Macau, China; Erasmus University of Rotterdam, Holanda; e Instituto Nacional de Salud de los Trabajadores, Cuba.

Nessa mesma perspectiva, o CIADS apresenta uma nova identidade visual, mais compatível com o alcance mundial que se pretende. Também passaremos a utilizar o ORCID para a identificação dos autores cujos artigos forem publicados no CIADS, contribuindo assim com um melhor compartilhamento da identificação das pesquisas.

As mudanças também acarretarão, de forma natural, uma ampliação no número de artigos submetidos, e para tanto, o CIADS já está preparado para avaliar e responder aos autores no menor espaço de tempo possível, vez que as informações contidas em um artigo têm uma temporalidade por vezes limitada, além de atender ao desejo de nosso autor com uma devolutiva mais célere sobre a sua submissão. Novas chamadas para credenciamento de avaliadores serão realizadas ao longo do ano, de modo a ampliar o seu número.

É com esse espírito aguerrido que o CIADS inaugura o ano de 2020, convidando os autores, pareceristas e demais colaboradores para trilhar juntos essa nova etapa de publicações.

Sandra Mara Campos Alves

Maria Célia Delduque

Editoras científicas

Cadernos Ibero-Americanos de Direito Sanitário (CIADS) 